\title{
Compounded pelleted fibre feed and hay pellets as substitutes for hay in horse feeding
}

\author{
MarkKu SaAstamoinen, Merja Manninen and Asko Rantanen
}

Saastamoinen, M., Manninen, M. \& Rantanen, A. 1992. Compounded pelleted fibre feed and hay pellets as substitutes for hay in horse feeding. Agr. Sci. Finl. 1: 225-232. (Agric. Res. Centre of Finland, Equine Res. Sta. SF-32100 Ypäjä, Finland.)

\begin{abstract}
Use of compounded pelleted fibre feed and ground pelleted hay as substitutes for hay in horse feeding was investigated. Thirty horses were divided into a control group and two experimental groups. The control horses received $6 \mathrm{~kg}$ hay per day. The horses in the two experimental groups were fed $3 \mathrm{~kg}$ hay per day and the remainder of their hay portion was substituted with a compounded pelleted fibre-rich feed or pelleted hay. The influence of the diet on health, haemoglobin $(\mathrm{Hb})$ and haematocrit $(\mathrm{Hc})$ values, blood serum glucose concentration, as well as on faecal microflora and weight change was investigated. The health of the horses was found to be good, and the influence of the diets on the $\mathrm{Hb}$ and $\mathrm{Hc}$ values and faecal microflora as well as on weight change was not statistically significant. Horses receiving compounded feed had a higher $(\mathrm{p}<0.05)$ mean blood glucose concentration than the other horses due to the molasses used as an ingredient $(25 \%)$ of the compounded feed. Compounded pelleted fibre-rich feed as well as pelleted hay, both made of ground raw materials, were found suitable substitutes for hay in the diet of horses.
\end{abstract}

Key words: blood glucose, coliform bacteria, E.coli, equine, faecal microflora, horse, nutrition

\section{Introduction}

Fibre is a useful attribute in a horse's diet (e.g. FRAPE 1986): It has a role both as a structural and filling material in the digestive tract of the horse. It is also a source of energy for the bacteria and ciliates in the caecum and colon. Furthermore, fibre suppresses any rapid fall in the $\mathrm{pH}$ in the large intestine and stimulates peristaltic contraction.

The primary source of fibre in horse feeding is long-stem roughage, mainly hay. However, poor hygienic quality, e.g. dusty and mouldy hay, is often encountered in practice, and may cause health problems, such as illnesses of the respiratory organs and digestive tract of the horse. Thus, suit- able substitutes and supplements for poor quality hay are needed.

Use of pelleted feed in horse feeding has been reported by some researches. Most of these previous reports have dealt with whole plant pellets. For example, whole oat plant pellets can replace a considerable part of hay and oats (KossiLA and LJUNG 1976) in horse feeding. Whole plant pellets (e.g. oats, corn) can also be used as the sole feed in horse diets (Kossila et al. 1979, Schurg et al. 1977). Also grass molasses pellets (PELTONEN et al. 1978) or beet pulp (HiNTZ 1989) have been found to be suitable feed and possible substitutes of hay for horses. According to JOHANSSON (1980) oats and hay could be replaced by a pelleted mixture with 
good quality straw.

This feeding experiment was conducted to study the use of compounded pelleted fibre-rich feed, and ground pelleted hay as substitutes for long hay in horse diets, and to determine their influence on health, haematology, faecal microflora and weight change.

\section{Material and methods}

\section{Horses}

Fifteen warmblooded riding horses (11 geldings, 4 mares) aged 4 to 15 years ( $8.1 \pm 4.0$ years) and fifteen Finnhorses (6 geldings, 5 mares, 1 stallion) aged 5 to 13 years $(7.3 \pm 2.0$ years) were divided into a control group and two experimental groups. The groups were balanced for breed, age and sex differences. Of the Finnhorses, 7 were riding horses and 8 were trotters. The horses were exercised $1 \frac{1}{2}$ hours per day (light or moderate work). The mean body weight was $567 \mathrm{~kg}$ for the warmblooded riding horses and $531 \mathrm{~kg}$ for the Finnhorses $(537 \mathrm{~kg}$ for riding horses; $529 \mathrm{~kg}$ for trotters).

\section{Feeds and feeding}

Throughout the 91-day feeding trial the horses were fed according to their body weight, amount of exercise and body condition. The diet was balanced to meet the nutritional requirements of horses engaged in light work (SALO et al. 1982). Prior to starting the feeding trial the horses were orally treated with anthelmintic.

The horses were individually fed three times per day. Feed samples were collected daily and the feeds were analyzed by standard methods. The FU (feeding unit) and DCP (digestible crude protein) values were calculated according to Finnish feeding tables (SALo et al. 1982), and ME (metabolizable energy) values according to MAFF (1975).

The feeding values and composition of the feeds are presented in Table 1. The hay was timothydominated (cut at full-bloom stage) and artificially dried. Hay pellets were made of young mixed hay.
Table 1. Composition and feeding values of the feeds.

\begin{tabular}{|c|c|c|c|c|c|}
\hline & Hay & $\begin{array}{l}\text { Com- } \\
\text { pounded } \\
\text { feed }\end{array}$ & $\begin{array}{l}\text { Pelleted } \\
\text { hay }\end{array}$ & Oats & $\begin{array}{l}\text { Wheat } \\
\text { bran }\end{array}$ \\
\hline $\begin{array}{l}\text { Dry matter } \% \\
\text { Contents of } \\
\text { Dry matter }(\%)\end{array}$ & 88.6 & 91.3 & 88.5 & 87.0 & 88.0 \\
\hline Crude fibre & 35.2 & 19.3 & 27.1 & 12.9 & 11.0 \\
\hline Crude prot. & 9.0 & 11.6 & 18.6 & 12.3 & 17.0 \\
\hline Crude fat & 2.3 & 2.6 & 4.2 & 5.1 & 5.0 \\
\hline Ash & 7.1 & 7.9 & 8.2 & 2.9 & 6.0 \\
\hline \multicolumn{6}{|l|}{ Feed values } \\
\hline $\mathrm{kg} / \mathrm{FU}$ & 2.54 & 1.50 & 1.65 & 1.20 & 1.39 \\
\hline $\mathrm{ME} \mathrm{MJ} / \mathrm{kg} \mathrm{DM}$ & 8.2 & 9.9 & 9.9 & 11.8 & 11.5 \\
\hline DCP g/FU & 102 & 111 & 193 & 103 & 135 \\
\hline
\end{tabular}

$\mathrm{FU}=$ feed unit; DCP = digestible crude protein;

$\mathrm{ME}=$ metabolizable energy

After cutting the hay was dried at a high temperature, ground and pressed into $8 \mathrm{~mm}$ diameter pellets. The ingredients of the pelleted compounded feed ( $8 \mathrm{~mm}$ diameter pellets) were molasses $(25 \%)$, dried ground hay $(25 \%)$ and barley hulls and bran ( $50 \%)$. Barley hulls and bran are byproducts of the integrated ethanol-starch process (NÄsI 1988). The digestibility of these by-products has been reported to be low (NÄsı 1988). The feeds differed clearly from each other in their crude fibre and crude protein contents.

In the two experimental groups, the horses received on the average $3 \mathrm{~kg}$ long-stem hay per day and $2.4 \mathrm{~kg}$ either pelleted compounded fibre feed (CF-group) or ground pelleted hay (PH-group). Horses in the control group (C-group) were given 6 $\mathrm{kg}$ long-stem hay and $300 \mathrm{~g}$ wheat bran per day. All horses were given 1 to $4.5 \mathrm{~kg}$ oats according to their amount of exercise and body condition. The diets were also supplemented with a mineral concentrate. Each horse had an automatic drinking bowl.

\section{Blood and faecal sampling}

Blood and faecal samples (6 samples/horse) were collected at two-week intervals during the feeding 
trial. Samples were taken prior to exercise, approximately 2 hours after morning feeding.

Blood samples were taken from the jugular vein into evacuated blood collection tubes for serum glucose, haemoglobin $(\mathrm{Hb})$ and haematocrit $(\mathrm{Hc}$, packed cell volume) determinations. Faecal samples were collected from the rectum to investigate the faecal microflora.

\section{Chemical analysis and counting of bacteria}

Blood serum glucose $(\mathrm{mmol} / \mathrm{l})$ was determined photometrically by the glucose-dehydrogenase method (BORGMEYER 1974, HENRY 1974) with Gilford Stasar-spectophotometry. $\mathrm{Hb}(\mathrm{g} / \mathrm{l})$ was determined by cyanmethemoglobin and Hc by microcapillary methods.

In the faecal samples, the number of colonies $\left(10^{3} / \mathrm{g}\right)$ of E.coli and other coliform bacteria were counted (MẢNSSON 1957). Counting continued up to $100 \times 10^{3} / \mathrm{g}$. Larger numbers of colonies indicate a very good status and balance of intestinal microflora (Yhtyneet laboratoriot 1985). In addition, the range of faecal streptococci and moulds was counted.

The colonies were counted and moulds determined visually after cultivating $5 \mathrm{~g}$ of rectal contents on EMB-agar at $37^{\circ} \mathrm{C}$. The incubation time was 24 hours.

\section{Weighing the horses}

The weight of the horses was measured at twoweek intervals. Furthermore, the state of the health of the horses was observed regularly.

\section{Statistical methods}

The differences between the feeding groups in the distribution among the classes of the number of faecal E.coli colonies $\left(<50 \times 10^{3}, 50-99 \times 10^{3}\right.$ and $\left.>100 \times 10^{3}\right)$ was tested by the $\chi^{2}$-test.

The data consisting of feed intake, blood parameters and body weights were subjected to an analysis of variance. In addition to the feeding group (CF, $\mathrm{PH}, \mathrm{C})$, the statistical model included the following factors: sex, breed, age, and in Finnhorses, class of purpose (riding or trotting) of the horse. The initial values (blood parameters or weights) were included in the statistical model as covariates.

\section{Results}

\section{Feed and nutrient intake}

The horses in each group had good appetites throughout the trial and they consumed all the feeds offered. The mean daily feed and nutrient intakes in each group are shown in Table 2. The difference in the mean digestible crude protein (DCP) intake between the feeding groups was statistically significant $(\mathrm{p}<0.001)$.

The mean dry matter (DM) and fibre intakes (per $100 \mathrm{~kg}$ bwt) of C-group horses were statistically significantly larger $(\mathrm{p}<0.01$ and $\mathrm{p}<0.001)$ than those of the other horses (Table 2).

Mean daily energy and digestible crude protein intakes of the warmblooded riding horses were 5.25 FU (66.5 MJ ME) and $539 \mathrm{~g} \mathrm{DCP.} \mathrm{For} \mathrm{Finn-}$ horses, the corresponding intakes were $5.20 \mathrm{FU}$ (73.6 MJ ME) and $623 \mathrm{~g} \mathrm{DCP}$, and 6.00 FU (83.2 $\mathrm{MJ} \mathrm{ME})$ and $718 \mathrm{~g} \mathrm{DCP}$, for riding horses and trotters, respectively.

The intake of dry matter was $7.69 \mathrm{~kg}$ for the warmblooded horses and $7.95 \mathrm{~kg}$ for the Finnhorses $(7.5 \mathrm{~kg}$ for riding horses and $8.4 \mathrm{~kg}$ for trotters).

Table 2. Mean daily feed and nutrient intake and crude fibre$\%$ of the diet in the different feeding groups.

\begin{tabular}{llll}
\hline & \multicolumn{3}{c}{ Group } \\
\cline { 2 - 4 } & $\begin{array}{l}\text { Control } \\
\text { (C) }\end{array}$ & $\begin{array}{l}\text { Compounded } \\
\text { feed (CF) }\end{array}$ & $\begin{array}{l}\text { Pelleted } \\
\text { hay (PH) }\end{array}$ \\
\hline FU & 5.46 & 5.35 & 5.55 \\
DCP g & 579 & 585 & 716 \\
DM & 8.44 & 7.53 & 7.84 \\
DM/100 kg bwt & 1.62 & 1.35 & 1.40 \\
Crude fibre & & & \\
$/ 100 \mathrm{~kg}$ bwt & 0.43 & 0.30 & 0.34 \\
Crude fibre-\% & 26.8 & 22.7 & 24.5 \\
\hline
\end{tabular}

$\mathrm{DM}=$ dry matter; bwt $=$ body weight 


\section{Influence on blood parameters}

There were no statistically significant differences between the feeding groups in the $\mathrm{Hb}$ and $\mathrm{Hc}$ values or the mean cell haemoglobin content (MCHC) (Table 3). However, the $\mathrm{Hb}$ and $\mathrm{MCHC}$ values varied between the samples of a single horse. A declining tendency in both $\mathrm{Hb}$ and $\mathrm{Hc}$ values was observed during the experiment in all horses.

Serum glucose concentration increased during the trial and the average concentration was highest in the CF-group horses (Fig. 1) $(\mathrm{p}<0.05)$. In the Cand $\mathrm{PH}$-group horses the serum glucose concentration remained quite constant. The difference in serum glucose concentrations between the groups at the beginning and end of the trial was not statistically significant (Table 3).

\section{Influence on faecal microflora}

No diarrhoea or other symptoms of a declined health status of the digestive tract were observed. The number of E.coli decreased in all horses during the course of the trial. The lowest number of E.coli was found in the faeces of the control horses.

The differences between the feeding groups in the distribution of horses among the classes by number of E.coli colonies were not statistically significant (Table 4).

In the case of the other coliform bacteria than E.coli, there was a considerable variation in bactera count between the samples from an individual animal. The average number of the colonies of coliform bacteria other than E.coli during the trial was $19.2 \times 10^{3} / \mathrm{g}\left(\mathrm{s}=7.6 \times 10^{3}\right)$.

Streptococci were found in the faeces of all the

Table 3. Blood parameters of the horses in the different feeding groups (LS-means and SE).

\begin{tabular}{|c|c|c|c|c|c|c|}
\hline & \multicolumn{5}{|c|}{ Group } & \\
\hline & \multicolumn{2}{|l|}{$\begin{array}{l}\text { Control } \\
\text { (C) }\end{array}$} & \multicolumn{2}{|c|}{$\begin{array}{l}\text { Compounded } \\
\text { feed (CF) }\end{array}$} & \multicolumn{2}{|l|}{$\begin{array}{l}\text { Pelleted } \\
\text { hay (PH) }\end{array}$} \\
\hline & $\mathrm{x}$ & SE & $\mathrm{x}$ & SE & $\mathrm{x}$ & SE \\
\hline \multicolumn{7}{|c|}{ Haemoglobin g/l } \\
\hline Initial & 133 & 2.9 & 135 & 3.1 & 135 & 2.8 \\
\hline Final & 131 & 2.7 & 119 & 3.0 & 126 & 2.7 \\
\hline Average $^{a}$ & 129 & 2.0 & 127 & 2.2 & 125 & 2.0 \\
\hline \multicolumn{7}{|c|}{ Haematocrit \% } \\
\hline Initial & 36.7 & 0.8 & 37.6 & 0.8 & 37.1 & 0.8 \\
\hline Final & 35.5 & 0.8 & 33.0 & 0.9 & 34.1 & 0.8 \\
\hline Average & 34.7 & 0.5 & 34.5 & 0.6 & 34.2 & 0.5 \\
\hline \multicolumn{7}{|l|}{$\mathrm{MCHC}$} \\
\hline Initial & 361 & 0.2 & 362 & 0.2 & 362 & 0.2 \\
\hline Final & 366 & 0.2 & 366 & 0.2 & 366 & 0.2 \\
\hline Average $^{a}$ & 371 & 2.9 & 370 & 3.2 & 368 & 2.9 \\
\hline \multicolumn{7}{|c|}{ Glucose mmol/l } \\
\hline Initial & 3.73 & 0.2 & 3.84 & 0.2 & 4.02 & 0.7 \\
\hline Final & 3.77 & 0.2 & 4.34 & 0.2 & 3.88 & 0.2 \\
\hline Average $^{a}$ & 3.74 & 0.1 & 4.05 & 0.1 & 3.79 & 0.1 \\
\hline
\end{tabular}

a Mean of the all values ( $\mathrm{n}=6$ for each horse) during the experiment $\mathrm{MCHC}=$ mean cell haemoglobin content 


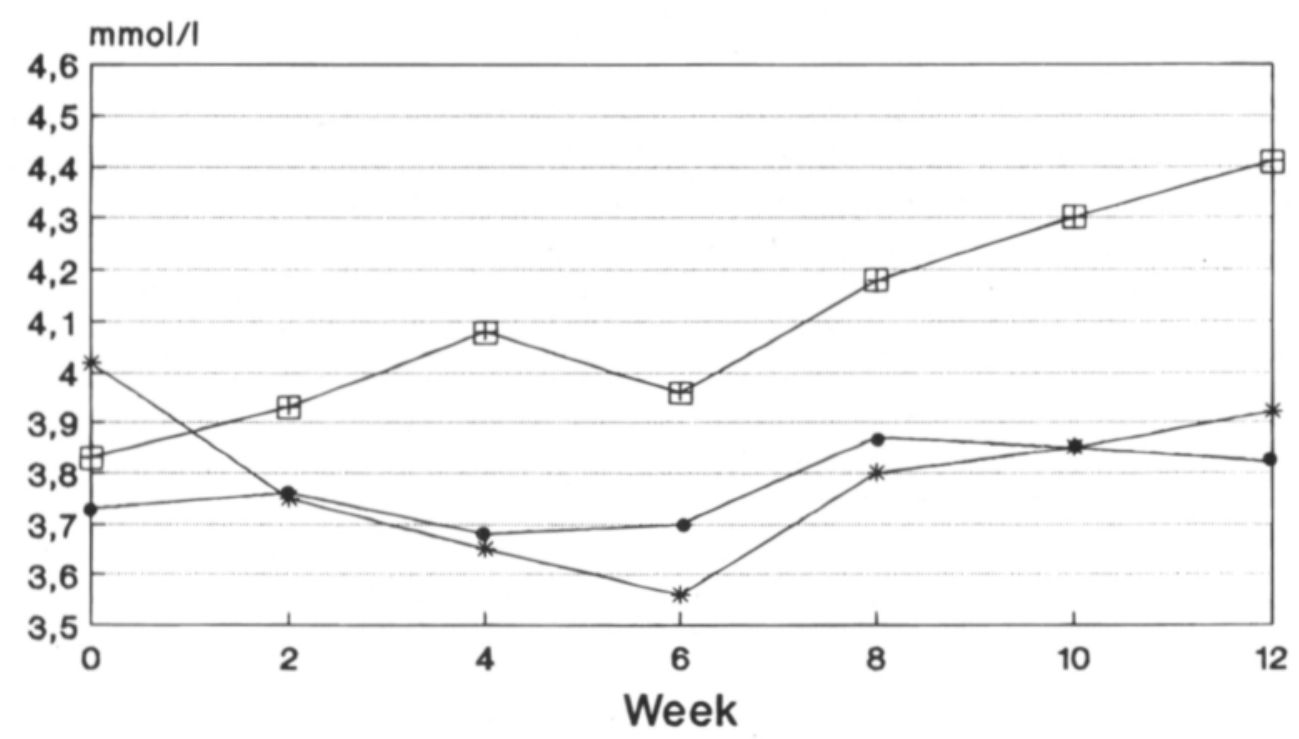

$\rightarrow$ Control $\quad$ - Compounded feed * Pelleted hay

Fig. 1. Change of the blood serum glucose concentration in the different feeding groups.

Table 4. Distribution of horses in classes according to number of E. coli colonies.

\begin{tabular}{llll}
\hline & & Group & \\
\cline { 2 - 3 } $\begin{array}{l}\text { E. coli } \\
\text { class }\end{array}$ & Control & Compounded & Pelleted \\
& (C) & feed (CF) & hay (PH) \\
& Initial Final & Initial Final & Initial Final
\end{tabular}

\begin{tabular}{lllllll} 
Initial & & & & & & \\
$<50^{*} 10^{3}$ & 0 & 4 & 0 & 3 & 0 & 4 \\
$50-100^{*} 10^{3}$ & 3 & 3 & 1 & 2 & 2 & 1 \\
$>100 * 10^{3}$ & 7 & 4 & 9 & 5 & 8 & 5 \\
\hline
\end{tabular}

Table 5. Live weight $(\mathrm{kg})$ and live weight changes of the horses in the different feeding groups (LS-means and SE).

\begin{tabular}{lcrr}
\hline & \multicolumn{3}{c}{ Group } \\
\cline { 2 - 4 } & $\begin{array}{l}\text { Control } \\
\text { (C) }\end{array}$ & $\begin{array}{l}\text { Compounded } \\
\text { feed (CF) }\end{array}$ & $\begin{array}{l}\text { Pelleted } \\
\text { hay (PH) }\end{array}$ \\
\hline Initial & 528.0 & 565.6 & 566.1 \\
SE & 12.4 & 12.3 & 13.3 \\
Final & 523.1 & 554.1 & 555.9 \\
SE & 7.9 & 7.3 & 8.6 \\
Change & -4.9 & -11.5 & -10.2 \\
SE & 8.7 & 9.4 & 8.5 \\
\hline
\end{tabular}

horses. Also moulds were found in many faecal samples, especially in the faeces of Finnhorses after the first four weeks of the trial.

\section{Influences on weight change and state of health}

The live weight of all the horses decreased during the course of the experiment (Table 5). The decline was smallest in the control group. The differences between the diets were not statistically significant.

The health of all the horses was normal throughout the experiment. The experimental feeds did not cause any skin symptoms and had no detrimental effect on hair quality. The pelleted feed diets cause a slight appetite depravity in some individuals.

\section{Discussion}

The state of the health of all the horses was good. $\mathrm{The} \mathrm{Hb}, \mathrm{Hc}$ and $\mathrm{MCHC}$ values observed for both breeds agreed with values reported for healthy horses in literature (KossILA et al. 1972, KÄÄNTEE 
1977, Pösö et al. 1983). Hb and Hc values may vary, e.g. owing to illness (SNOw and Vogel 1987).

The higher serum glucose concentrations of CFgroup horses compared to the other horses may be due to the molasses which was an ingredient $(25 \%)$ of the feed. The control horses were fed during the experiment the same diet as before the experiment, which may give an explanation for their relatively constant blood glucose levels.

The serum glucose content may be influenced by the amount of soluble carbohydrates in the diet, as well as by the forage-grain ratio and size of the meal (Kossila et al. 1972) and generally by the type of diet (ARGENZIO and HINTZ 1972). STULL and RODIEK (1988) found no differences in the serum glucose concentration between various studied diets.

Blood glucose concentration is an expression of a dynamic balance between glycogen breakdown and synthesis, as well as the production of glucose from other sources, e.g. propionate in the caecum. According to FORD and SIMMONS (1985), $7 \%$ of the total glucose production derived from propionate was produced in the caecum and the percentage was unaffected by the diet. Thus, it may be suggested that blood glucose concentration is also connected to the extent and rate of fermentation in the caecum. Most of the blood glucose, however, derived from the digestion of starch and low molecular carbohydrates in the small intestine (FORD and SIMMONS 1984).

The functioning of the digestive tract of the horses was normal. Faecal E.coli was used as an indicator of the microbial status and health of the digestive tract. The number of E.coli in faeces is a common indicator of the status of intestinal microflora in horses (i.a. Yhtyneet laboratoriot 1985). MÅNSSON (1957) reported a close connection between the state of health of the host animal and the intestinal and faecal microflora.

MÅNSSON (1957) reported that the influence of fodder on faecal coliform was not quantitative but qualitative. SYrJÄLÄ et al. (1976) found that the diet influenced the rumen microbiota of sheep both quantitatively and qualitatively.
Nurmio et al. (1973) found coli bacteria, faecal streptococci, lactobasilli, chlostridia, moulds and yeasts in the faeces of horses with normal digestive functions. High counts of coliforms and low counts of moulds have been found in the faeces of healthy horses (WIERUP and DiPIETRo 1981).

Skin changes - which were not observed in this study - are also indicators of the poor status of intestinal microflora (MÅNSSON 1957). Because a slight appetite depravity (wood chewing, coprophagy, eating of beddings) was observed in some horses especially at the beginning of the feeding trial, it was assumed that the pelleted feed diets might cause a reduction in gut fill and feed consumption time (HINTZ and LOY 1966, FRAPE 1986).

The requirement of crude fibre in adult horses is $16-18 \%$ in the dry matter of the diet, and the minimum daily requirement of long hay is $0.5-0.6 \mathrm{~kg}$ per $100 \mathrm{~kg}$ live weight (MEYER 1986). FraPE (1986) suggested intakes as low as $0.25-0.5 \mathrm{~kg}$ per $100 \mathrm{~kg}$ live weight for long hay.

The crude fibre content of all diets used in this experiment exceeded the minimum requirement suggested by MEYER (1986). The intake of long hay in both experimental groups was $0.55 \mathrm{~kg}$ per $100 \mathrm{~kg}$ live weight. The crude fibre content $(19.3 \%$ in DM) of the compounded pelleted feed offered an adequate amount of fibre for the normal functioning of the digestive tract of the horse. FRAPE (1986) recommends a crude fibre content of 14-15 $\%$ in compounded feeds for horses engaged in light or moderate work.

The decline in the body weight of all the horses might be due to the reduced feed intake during the experiment compared to the time before the experiment.

Both compounded pelleted fibre-rich feed and pelleted hay seemed to be suitable substitutes for hay in horse feeding. However, the cost of replacing other nutrients than fibre and the effect on feed intake, feeding behaviour and digestive physiology should also be considered (HINTZ 1989).

If hay pellets, or other whole plant pellets rich in protein are used, overfeeding of protein may be obvious in adult exercising horses. The feeding 
value of whole plant pellets generally depends on stage of maturity, fertilization and stem-to-leaf ratio of the plant. In compounded pelleted feeds fluctuations in feeding value and composition can be avoided by balancing the feeds for different nutrients. Furthermore, different kinds of by-products can be utilized.

Pelleting has been reported to decrease the digestiblity of fibre and dry matter both in horses (MEYER 1974, KossILA and LJUNG 1976) and cows (JARRIGE et al. 1973, UdEN 1988). However, HINTZ and LoY (1966) found no reduction in the digestibility of fibre or in the efficiency of feed utilization. KosSILA and LJUNG (1976) reported equal rates of passage for oat pellets and long hay.

The use of pelleted feeds in horse feeding has certain advantages, such as a more consistent balance of nutrients, less feed wastage, and less dust in the stable. To avoid different vices (wood chewing, coprophagy) only part of the long-stem forage can be recommended to be substituted in horse feeding.

\section{Conclusions}

No health disturbances or other detrimental effects were observed during the feeding experiment. Both compounded pelleted fibre-rich feed and pelleted hay were palatable and suitable replacements for hay and sources of crude fibre in the diet of horses. However, to avoid possible vices, only part of the hay can be recommended to be substituted in the diet.

\section{References}

Argenzio, R.A. \& HinTZ, H.F. 1972. Effect of diet on glucose entry and oxidation rates in ponies. J. Nutr. 102: 879-892.

BORGMEYer, H.U. 1974. Methoden der enzymatischen Analyse. Vol. 1, 3rd ed., Verlag Chemie. 175 p.

FoRD, J.H. \& Simmons, H.A. 1985. Gluconeogenesis from caecal propionate in the horse. Brit. J. Nutr. 53: 55-60.

FrAPE, D. 1986. Equine nutrition and feeding. 373 p. Longman, Essex.

HenRY, R.J. 1974. Clinical chemistry. Harper \& Row, New York. p. 1301-1302.

HinTZ, H.F. 1989. Alternative feeds for horses. Equine Practice 11: 10-11.

— \& LoY, R.G. 1966. Effect of pelleting on the nutritive value of horse rations. J. Anim. Sci. 25: 1059-1062.

-, Argenzio, R.A. \& Schryver, H.F. 1971. Digestion coefficients, blood glucose levels and molar percentage of volatile acids in intestinal fluid of ponies fed varying forage-grain ratios. J. Anim. Sci. 33: 992-995.

Jarrige, R., Demarquilly, C., Journet, M. \& Beranger, C. 1973. Nutritive value of processed dehydrated forages with special reference to the influence of physical form and particle size. Proc. 1st Int. Congr. Green Crop Drying, p. 99-118.

JoHANSSON, K. 1980. Digestion experiment with a pelleted feed mixture and straw to adult horses. Paper. 31st Ann. Meet. of Eur. Assoc. for Anim. Prod. 5 p.

Kern, D.L., Slyter, L.L., Weaver, J.M., LefFel, E.C. \&
Samuelson, G. 1973. Pony cecum vs. steer rumen: Microbial and chemical characteristics of intestinal ingesta. J. Anim. Sci. 38: 559-564.

Kossila, V., TanhuanpäÄ, E., Virtanen, E. \& Luoma, E. 1972. Blood levels of hemoglobin, glucose, cholesterol, minerals and trace elements in saddle horses. I. Differences due to age and maintenance. J. Scient. Agric. Soc. Finl. 44: 249- 257.

— \& LJUNG, G. 1976. Value of whole oat plant pellets in horse feeding. Ann. Agric. Fenn. 15: 316-321.

-, HeIKKILÄ, T. \& TUPAMÄKI, A. 1979. Whole oat plant pellets as sole source of diet for horses. Paper. 30th Ann. Meet. of Eur. Assoc. for Anim. Prod. 4 pp.

KÄÄNTEE, E. 1977. Hematological values of the Finnish warm-blooded trotters in racing condition. J. Scient. Agric. Soc. Finl. 49: 167-175.

MAFF 1975. Energy allowances and feeding systems for ruminants. Ministry of Agriculture, Fisheries and Food. Technical Bulletin 33. 9 p. London.

MEYER, H. 1974. Ernährung des Pferdes. In: Löwe, H. \& Meyer, H. (eds.). Pferdezucht und Pferdefütterung. Eugen Ulmer, Stuttgart. p. 228-349.

- 1986. Pferdefütterung. Paul Parey, Berlin. 205 pp.

MÅnsson, I. 1957. The intestinal flora in horses with certain skin Changes. Acta Path.et Microbiol. Scand. Suppl. 119. 102 pp.

Nurmio, P., KoIranen, L. \& TUPAmĀKI, A. 1973. The faecal microflora of horses. (In Finnish - English summary). 
Suomen eläinläăkärilehti 79: 668-681.

NÄSI, M. 1988 Evaluating barley feed fractions from integraded ethanol-starch production in diets of ruminants. J. Agric. Sci. Finl. 60: 701-709.

Peltonen, T., Kossila, V., Syrjälä, L. \& Immonen, I. 1978. Feeding value of grass molasses pellets and their influence on the faecal microbiota of horses. Ann. Agric. Fenn. 17: 109-114.

Pösö, A.R., Soveri, T., \& OKsanen, H.E. 1983. The effect of exercise on blood parameters in Standadrdbred and Finnish-bred horses. Acta Vet. Scand. 24: 170-184.

SAlo, M.-L., TUORI, M. \& KIISKINEN, T. 1982. Feed tables and feeding recommendations. (In Finnish), $70 \mathrm{p}$. Helsinki.

Schurg, W.A., Frei, D.L., Cheeke, P.R. \& Holtan, D.W. 1977. Utilization of whole corn plant pellets by horses and rabbits. J. Anim. Sci. 45: 1317-1321.

SNow, D.H. \& Vogel, C.J. 1987. Equine fitness. The care and training of the athletic horse. 271 p. Longman, London.

Stull, C. \& Rodiek, A.V. 1988. Responses of blood glucose, insulin and cortisol concentrations to common equine diets. J. Nutr. 118: 206-213.

SyruÄlä, L., Saloniemi, H. \& LaAlahti, L. 1976. Composition and volume of the rumen microbiota of sheep fed grass silage with different sucrose, starch and cellulose supplements. J. Scient. Agric. Soc. Finl. 48: 138-153.
UDEN, P. 1988. The effect of grinding and pelleting hay on digestibility, fermentation rate, digesta passage and rumen and faecal particle size in cows. Anim. Feed Sci. and Tech. 19: 145-157.

WieruP, M. \& DiPIETRO, J.A. 1981. Bacteriologic examination of equine fecal flora as a diagnostic tool for equine intestinal clostridiosis. Am. J. Vet. Res. 42: 2167-2169.

Yhtyneet laboratoriot 1985 Laboratory examinations of horses. (In Finnish). 48 p. Yhtyneet Laboratoriot Oy. Helsinki.

\section{Manuscript received October 1991}

Markku Saastamoinen

Agricultural Research Centre of Finland

Equine Research Station

SF-32100 Ypäjä, Finland

Merja Manninen

Agricultural Research Centre of Finland

Institute of Animal Production

SF-31600 Jokioinen, Finland

Asko Rantanen

Alko Ltd.

SF-05200 Rajamäki, Finland

\title{
SELOSTUS
}

\section{Pelletöidyn kuiturehuseoksen ja pelletöidyn heinäjauhon käyttö heinän korvaajana hevosen ruokinnassa}

\author{
Markku Saastamoinen, Merja Manninen ja Asko Rantanen \\ Maatalouden tutkimuskeskus ja Oy Alko Ab
}

Pelletöidyn runsaasti kuitua sisältävăn rehuseoksen ja pelletöidyn heinäjauhon käyttöä heinän korvaajana hevosen ruokinnassa tutkittiin 30 hevosella. Kontrolliryhmäăn kuuluneet hevoset saivat päivăssă $6 \mathrm{~kg}$ heinäa. Kahteen koeryhmään kuuluneet hevoset saivat heinää $3 \mathrm{~kg}$, ja loppu niiden henäannoksesta korvattiin em. koerehuilla. Ruokinnan vaikutusta tutkittiin hevosen terveyteen, veren hemoglobiini- ja hematokriittiarvoihin ja glukoosipitoisuuteen, sonnan mik- robistoon ja elopainon muutokseen. Hevosten terveys säilyi hyvänä, eikä dieetillă ollut vaikutusta veriarvoihin, sonnan mikrobistoon tai elopainon muutokseen. Pelletöityä rehuseosta saaneiden hevosten veren glukoosipitoisuus oli korkeampi kuin muiden hevosten, mikă johtui rehun sisăltămästä $(25 \%)$ melassista. Sekä pelletöity runsaskuituinen rehuseos että pelletöity heinäjauho sopivat hyvin heinäannoksen osittaisiksi korvaajiksi hevosen ruokinnassa. 